\title{
The assessment of the possibilities of improvement of the extraction evenness in multicyclone dedusters fitted in special vehicles
}

\begin{abstract}
A modification of the structure of the dust collector has been made through partitioning of its chamber into separate dedusting channels to which a number of cyclones was assigned. Using the model of the dust collector a preliminary selection of the heights $h 1, h 2, \ldots$. hi, at the intake was made of the individual channels of the dust collector sections to ensure identical flow resistance of the airstream through these channels. The model investigations of the sections of the dust collector were verified in flow investigations. The values of the stream was measured extracted from individual cyclones for several variants of the dust collector. An assessment of the improvement of the dedusting efficiency from individual cyclones has been performed.
\end{abstract}

Key words: combustion engines, air filtration, multicyclone, dust collector, extraction efficiency

\section{Badania możliwości poprawy równomierności odsysania pyłu z osadnika multicyklonu filtru powietrza pojazdu specjalnego}

\begin{abstract}
W artykule opisano zmiane formy konstrukcyjnej osadnika pytu przez podziat komory osadnika pyłu na odizolowane od siebie kanaty odsysania, którym przyporządkowano określona liczbę cyklonów. Wykorzystując model osadnika pyłu, dokonano wstepnego doboru wysokości na wylocie h1, h2, ... hi, kolejnych kanałów odsysajacych segmentu osadnika pyłu pod względem jednakowych oporów przepływu strumieni powietrza przez kanały. Badania modelowe segmentu osadnika pylu zweryfikowano podczas badań przepływowych. Pomierzono wartości strumieni powietrza odsysanego z pojedynczych cyklonów dla kilku wariantów osadnika pytu. Dokonano oceny poprawy równomierności odsysania pyłu z pojedynczych cyklonów multicyklonu filtru powietrza.

Słowa kluczowe: silniki spalinowe, filtracja powietrza, multicyklon, osadnik pyłu, równomierność odsysania
\end{abstract}

\section{Introduction}

Vehicle engines operated in heavily dusted conditions (exceeding $1 \mathrm{~g} / \mathrm{m}^{3}$ ) are fitted with dual stage filter where the first stage of the air cleaning are multicyclones that are composed of several filter elements (individual cyclones) in a parallel configuration. The dust separated in each of the cyclones is accumulated in a common dust collector (container) and subsequently it is eliminated through continuous extraction.

Dust extraction from the dust collector significantly increases the dedusting efficiency. While maintaining identical flow criteria and extraction rate the performance of the multicyclone (dedusting efficiency) as a whole are much worse, sometimes up to $10 \%$ as compared to a single cyclone [ $1-4$, 9]. Numerous experiments have shown that the simplest solution of directing the dust from the multicyclone deduster to a common dust collector from which the stream is extracted through one or two outlets results in a significant drop in the deduster efficiency. The reason for the drop in the efficiency of the multicyclones is the uneven distribution of gas to the individual cyclones caused by backflows.

The basic reason for the unevenness of the airstream extracted from the individual cyclones is different flow resistance of these airstreams inside the dust collector on the line cyclone - extraction pipe. This results from different lengths of the said lines determined by the location of the cyclone against the pipe and the interaction of the walls of the dust collector and the streams extracted close to the cyclones.

\section{Wstęp}

Silniki pojazdów mechanicznych eksploatowanych w warunkach dużego zapylenia powietrza (najczęściej powyżej $1 \mathrm{~g} / \mathrm{m}^{3}$ ) wyposaża się w filtry dwustopniowe, w których pierwszym stopniem oczyszczania powietrza są multicyklony będące zespołami składającymi się z kilku do kilkudziesięciu elementów filtracyjnych (cyklonów) połączonych równolegle. Odseparowany w każdym z pojedynczych cyklonów pył jest gromadzony we wspólnym kolektorze (pojemniku), zwanym osadnikiem pyłu, skąd następnie jest usuwany najczęściej przez ciągłe odsysanie.

Zastosowanie odsysania pyłu z osadnika powoduje zauważalny wzrost jego skuteczności odpylania. Przy zachowaniu jednakowych kryteriów przepływu i tym samym jednakowym stopniu odsysania, osiągi multicyklonu (skuteczność odpylania) jako całości bywają jednak znacznie gorsze, niekiedy o około $10 \% \mathrm{w}$ stosunku do pojedynczego cyklonu $[1-4,9]$, z których jest on zbudowany. Liczne doświadczenia wykazały, że najprostsze rozwiązanie odprowadzania zanieczyszczeń z odpylacza multicyklonowego do jednego, wspólnego dla wszystkich cyklonów osadnika, z którego strumien odsysany jest dwoma lub jednym króćcem, powoduje wyraźny spadek skuteczności odpylacza. Przyczyną spadku efektywności odpylania multicyklonów jest nierównomierny rozdział gazu na poszczególne cyklony, spowodowany zwrotnymi przepływami.

Zasadniczą przyczyną nierównomierności strumieni odsysających z poszczególnych cyklonów jest zróżnicowanie 
Another reason may be the mutual interaction of the swirled streams flowing out of multiple cyclones to the common dust collector. A simple conclusion follows: the system of dust extraction to a common dust collector does not ensure identical extraction rate from each cyclone in a multicyclone system, hence the need to seek better solutions related to the dust extraction. One of the solutions has been shown on the example of an extraction system in a multicyclone of an air cleaner (special vehicle BWP-1).

A general design of the multicyclone of a BWP-1 air cleaner is quit simple. On a rectangular plate (Fig. 1) i.e. the upper part of the dust collector, cyclones are fitted horizontally in three columns. The BQP-1 multicyclone is built of 39 (three columns, 13 cyclones) horizontally fitted reverse cyclones with a tangent intake of the inner diameter of $\mathrm{D}=35 \mathrm{~mm}$.

The dust collector of the multicyclone is a hollow chamber formed into a flat cuboid whose bottom is slightly skewed lengthwise. The dust extraction is realized at a single point a)
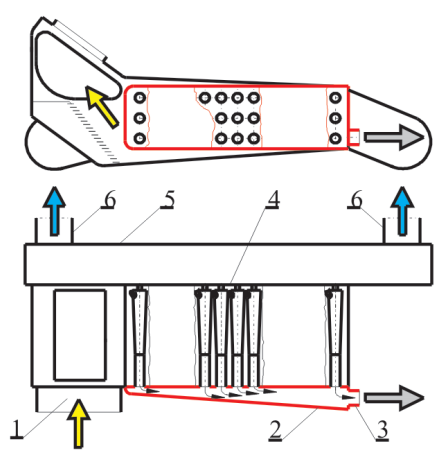

b)

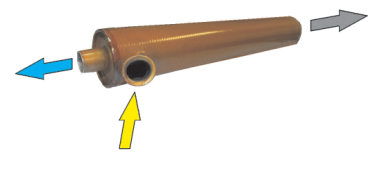

Airstream $\Rightarrow$ contaminated with dust
$\Rightarrow$ dedusted
$\Rightarrow$ extracted with the dust
(ejective ex-traction)
Fig. 1. Functional schematics of the air cleaner in a BWP-1 special vehicle: a) location of the dust collector, b) a cyclone in the multicyclone system, 1 - air intake pipe, 2 -dust collector in a multicyclone, 3 -extraction pipe, 4 - multicyclone 5 - main collector, 6 - air outlet pipe

Rys. 1. Schemat funkcjonalny filtru powietrza pojazdu specjalnego BWP-1: a) lokalizacja osadnika pytu, b) cyklon multicyklonu, 1 - króciec wlotowy powietrza, 2 - osadnik pylu multicyklonu, 3-króciec odsysania, 4-multicyklon, 5 - kolektor zbiorczy, 6 -króćce powietrza wylotowego oporów przepływu tych strumieni w osadniku odpylacza, na odcinku cyklon - króciec odsysania. Wynika ono przede wszystkim z niejednakowych długości wspomnianych odcinków, zdeterminowanych położeniem cyklonu względem króćca oraz oddziaływaniem ścian osadnika na strumienie odsysane położonych w ich pobliżu cyklonów. Innym powodem może być wzajemne oddziaływanie zawirowanych strumieni wypływających z wielu cyklonów do wspólnego osadnika pyłu. Nasuwa się stąd prosty wniosek, że system odprowadzania zanieczyszczeń do jednego wspólnego osadnika nie zapewnia jednakowego stopnia odsysania z każdego cyklonu wchodzącego w skład multicyklonu. Wynika z tego konieczność poszukiwania doskonalszych rozwiązań sposobu odprowadzenia strumienia odsysania. Jeden ze sposobów pokazano na przykładzie systemu odsysania pyłu z multicyklonu filtru powietrza pojazdu specjalnego BWP-1.

Ogólna konstrukcja multicyklonu filtru powietrza BWP-1 jest prosta. Na prostokątnej płycie (rys. 1), będącej górną ścianą osadnika pyłu umocowane są cyklony, rozmieszczone poziomo w trzech kolumnach. Multicyklon BWP-1 zbudowany jest z 39 (trzy kolumny po 13 cyklonów), poziomo zamocowanych cyklonów zwrotnych z wlotem stycznym o średnicy wewnętrznej $\mathrm{D}=35 \mathrm{~mm}$.

Osadnik pyłu multicyklonu jest pustą wewnątrz komorą o kształcie zbliżonym do płaskiego prostopadłościanu, którego dno jest lekko skośne na całej jego długości. Odsysanie pyłu realizowane jest punktowo jednym króćcem umieszczonym na ścianie czołowej osadnika pyłu multicyklonu (rys. 1). Cyklony względem otworu wylotowego króćca odsysania są rozmieszczone w różnej odległości. Ostatni w rzędzie cyklon znajduje się w odległości 12 razy większej niż cyklon położony najbliżej otworu wylotowego króćca odsysania. Ma to duży wpływ na wartość strumienia odsysania z poszczególnych cyklonów (rys. 2).

$\mathrm{Z}$ analizy przedstawionych na rysunku 2 charakterystyk wynika, że największe wartości strumieni odsysanych $\mathrm{Q}_{\mathrm{SC}} \mathrm{z}$ cyklonów górnej kolumny multicyklonu występują, niezależnie od wartości głównego strumienia odsysania $\mathrm{Q}_{\mathrm{SF}}$, dla cyklonów znajdujących

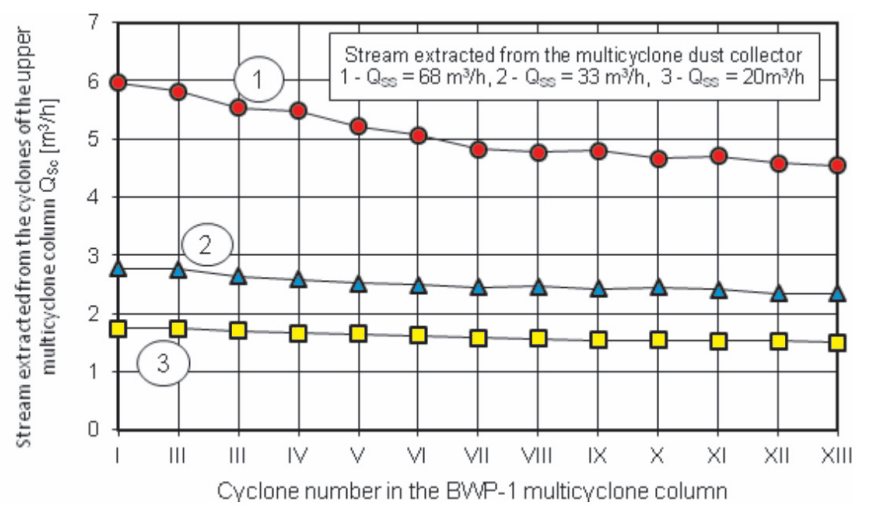

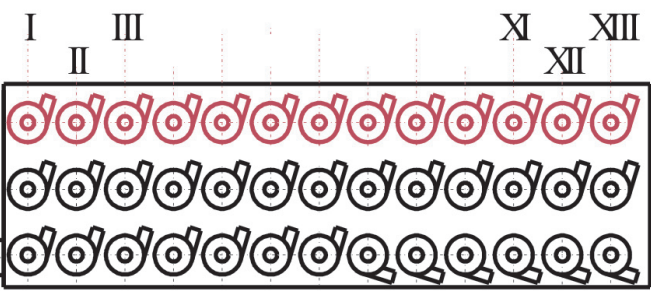

Fig. 2. Values of the streams $\mathrm{Q}_{\mathrm{SC}}$ extracted from the individual cyclones of the upper column of the multicyclone (BWP-1) Rys. 2. Wartości strumieni odsysanych $Q_{S C}$ z pojedynczych cyklonów górnej kolumny multicyklonu BWP-1 
through a pipe on the front wall of the multicyclone (Fig. 1). The Cyclones are located at different distances from the extraction pipe. The last cyclone in the row is located at a distance that is 12 times greater than the cyclone closest to the extraction pipe. This significantly influences the extraction from the individual cyclones (Fig. 2).

From the characteristics presented in Fig. 2 it results that the greatest values of the streams QSC extracted from the cyclones of the upper column of the multicyclone are in the range of $\mathrm{Q}_{\mathrm{SC}}=1.83 \div 6.4 \mathrm{~m}^{3} / \mathrm{h}$, irrespective of the value of the main extraction stream $\mathrm{Q}_{\mathrm{SF}}$, for the cyclones that are the closest to the extraction pipe of the dust collector of the multicyclone. As the distance of the cyclone location grows a systematic drop in the extraction stream $\mathrm{Q}_{\mathrm{SC}}$ takes place and for cyclone XIII the $\mathrm{Q}_{\mathrm{SC}}$ streams assume values in the range $\mathrm{Q}_{\mathrm{SC}}=1.42 \div 4.32 \mathrm{~m}^{3} / \mathrm{h}$ i.e. more than $30 \%$ lower. This clearly impacts the efficiency of the cyclone dedusting.

In order to better monitor the test results the values of $\mathrm{Q}_{\mathrm{SC}}$ for the subsequent cyclone of the column and for the same main extraction stream $Q_{\mathrm{SS}}$ have been connected with straight lines. Ensuring identical values of the streams extracted from all multicyclones requires a modification of the whole system, particularly the dust collector.

\section{The concept of dedusting from a multicyclone}

In order to ensure an even extraction from the individual cyclones of the multicyclone the most appropriate seems the modification of the structure of the multicyclone dust collector through partitioning of the collector space into sections and each section into independent isolated extraction channels that should be assigned to groups of individual cyclones $[5,7,8]$. Schematics of such partitioning of the dust collector into sections and the sections into extraction channels (for the BWP-1 vehicle) has been shown in Fig. 3.

The dust collector chamber of the multicyclone has been partitioned into three identical and independent sections $\mathrm{S}$ of width $\mathrm{a}$. Each has been assigned a column of 13 cyclones (I, II, III, ..., XII, XIII). The section can have different numbers of extraction channels and each can have a different number of cyclones assigned. The chambers of the dust collectors of the sections (Fig. 3) have been divided with horizontal (parallel against one another and against the bottom) partitions into four separate extraction channels of different heights $h_{1}, h_{2}, h_{3}, h_{4}$. The basic problem when dividing the chamber of the dust collector of each section into the extraction channels is to set the horizontal partitions on appropriate heights $h_{1}, h_{2}, \ldots, h_{i}$. To this end the authors developed a calculation algorithm that allows an initial selection of the heights at the outlet $h_{1}, h_{2}, \ldots ., h_{i}$, of the subsequent extraction channels of the dust collector so that identical flow resistance of the air through the channels is maintained $[5,7,8]$. The final selection of the number and height $h_{1}, h_{2}, \ldots ., h_{i}$ had to be made during experimental research on a separate section of the multicyclone. Such research has been carried out for a section of a multicyclone fitted in the BWP-1 vehicle. się najbliżej otworu wylotowego króćca odsysania osadnika pyłu multicyklonu i zawierają się w zakresie $\mathrm{Q}_{\mathrm{SC}}=1,83 \div 6,4$ $\mathrm{m}^{3} / \mathrm{h}$. Wraz z oddalaniem się położenia cyklonów od tego miejsca następuje systematyczny spadek strumieni $Q_{S C}$ i dla cyklonu nr XIII strumienie $\mathrm{Q}_{\mathrm{SC}}$ przyjmują wartości w zakresie $\mathrm{Q}_{\mathrm{SC}}=1,42 \div 4,32 \mathrm{~m}^{3} / \mathrm{h}$, a więc o ponad $30 \%$ mniejsze. Ma to niewątpliwie wpływ na skuteczność odpylania cyklonów.

W celu lepszego śledzenia wyników badań wartości $Q_{\mathrm{SC}}$ dla kolejnych cyklonów kolumny i dla tego samego głównego strumienia odsysania $\mathrm{Q}_{\mathrm{SS}}$ połączono liniami prostymi. Zapewnienie jednakowych wartości strumieni odsysających ze wszystkich minicyklonów wymaga wykonania modyfikacji układu odsysania zanieczyszczeń, a w szczególności osadnika pyłu.

\section{Koncepcja układu odsysania pyłu z multicyklonu}

Dla zapewnienia równomiernego odsysania strumieni z pojedynczych cyklonów multicyklonu najbardziej odpowiedni wydaje się sposób polegający na zmianie struktury osadnika pyłu multicyklonu, przez podział przestrzeni osadnika przegrodami na segmenty, a segmentu na niezależne, odizolowane od siebie kanały odsysania, którym należy przyporządkować określone grupy pojedynczych cyklonów $[5,7,8]$. Schemat ideowy podziału osadnika multicyklonu pojazdu specjalnego BWP-1 na segmenty, a segmentu na kanały odsysania przedstawiono na rys. 3 .

Komorę osadnika pyłu multicyklonu podzielono na szerokości ścianami wewnętrznymi (przegrodami) na trzy jednakowe i niezależne części (segmenty S) o szerokości a. Każdemu przyporządkowano kolumnę 13 (I, II, III, ... XII, XIII) cyklonów, co stanowi segment. Segment może zawierać różne liczby kanałów odsysania, a do każdego może być przypisana inna liczba cyklonów. Komory osadników segmentów (rys. 3) podzielono poziomymi (równoległymi do siebie i do dna osadnika) przegrodami na cztery odrębne kanały odsysania o różnych wysokościach $h_{1}, h_{2}, h_{3}, h_{4}$. Podstawowym problemem przy podziale komory osadnika segmentu na kanały odsysania jest ustawienie poziomych

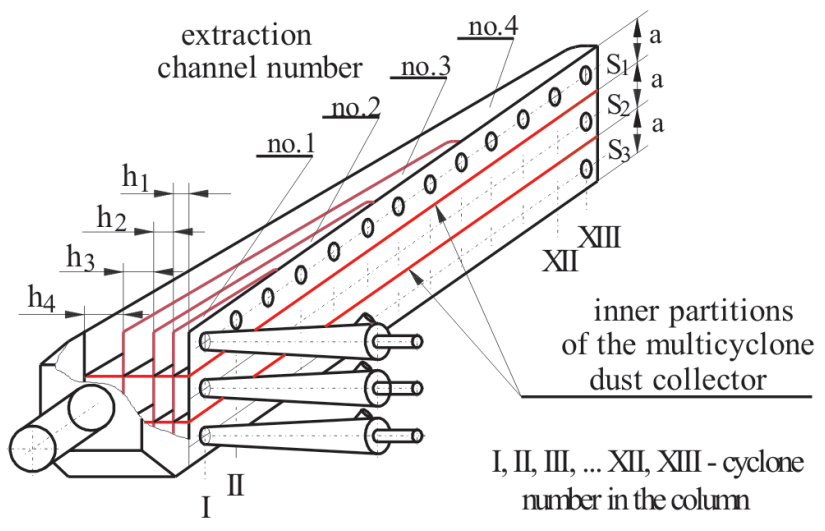

Fig. 3. Schematics of the dust collector partitioning in the multicyclone of the air cleaner [7]

Rys. 3. Schemat ideowy podziału osadnika pylu multicyklonu filtru powietrza na segmenty [7] 


\section{The range and methodology of the flow investigations}

The aim of the flow investigations was the experimental evaluation of the proposed concept of modification of the inner structure of the section of the dust collector in a multicyclone system (BWP-1) in order to obtain an improvement in the efficiency of the extraction from individual cyclones, which should positively influence the dedusting efficiency of the multicyclone.

The investigations determined the values of the streams $\mathrm{Q}_{\mathrm{SC}}$ extracted from individual cyclones of the separated section (column) of a multicyclone in the air cleaner. The tests were performed under conditions in which the extraction stream $\mathrm{Q}_{\mathrm{SS}}$ flows through the dust collector with the extraction rate $\mathrm{m}_{0}=4,8$ and $16 \%$ and engine air demand $\mathrm{Q}_{\mathrm{Sil}}$ corresponding to the engine speed of the maximum power.

In order to determine the values of the streams $Q_{S C}$ extracted from the individual cyclones of a section in the multicyclone deduster an indirect method was used that consisted in measuring of the intake stream $\mathrm{Q}_{0 \mathrm{C}}$ to the cyclone (which, if the cyclone outlet stream is $\mathrm{Q}_{\mathrm{GC}}=0$, assumes the value of $\left.\mathrm{Q}_{\mathrm{OC}}=\mathrm{Q}_{\mathrm{SC}}[6,7]\right)$. Such a case takes place when the outlet holes from all the cyclones are closed and the stream $\mathrm{Q}_{\mathrm{SS}}$ is extracted from the section of the dust collector that is the sum of the $\mathrm{Q}_{\mathrm{SC}}$ streams from the individual cyclones.

$$
\mathrm{Q}_{\mathrm{sS}}=\sum_{\mathrm{j}=\mathrm{I}}^{\mathrm{J}} \mathrm{Q}_{\mathrm{SC}}
$$

where: I, II, II, ..., j, ...., J-subsequent number of the cyclone in the column.

Stream $\mathrm{Q}_{\mathrm{SS}}$ extracted from the dust collector of a multicyclone was determined from the relation:

$$
\mathrm{Q}_{\mathrm{SS}}=\frac{\mathrm{Q}_{\mathrm{SF}}}{\mathrm{m}_{\mathrm{S}}}
$$

przegród na odpowiednich wysokościach $h_{1}, h_{2}, \ldots, h_{i}$. W tym celu wykorzystano opracowany algorytm obliczeń, który umożliwia wstępny dobór wysokości na wylocie $\mathrm{h}_{1}, \mathrm{~h}_{2}, \ldots$, $\mathrm{h}_{\mathrm{i}}$, kolejnych kanałów odsysających segmentu osadnika pyłu pod względem jednakowych oporów przepływu strumieni powietrza przez kanały $[5,7,8]$. Ostateczny dobór liczby i wysokości $h_{1}, h_{2}, \ldots ., h_{i}$ kanałów należy przeprowadzić podczas badań eksperymentalnych wydzielonego segmentu multicyklonu. Badania takie wykonano dla segmentu multicyklonu filtru powietrza pojazdu specjalnego BWP-1.

\section{Zakres i metodyka badań przepływowych}

Celem badań przepływowych była eksperymentalna ocena zaproponowanej koncepcji zmian struktury wewnętrznej segmentu osadnika pyłu multicyklonu filtru powietrza pojazdu specjalnego BWP-1 ze względu na poprawę równomierności odsysania z pojedynczych cyklonów, co pozytywnie powinno wpłynąć na skuteczność odpylania multicyklonu.

Zakres badań obejmował określenie wartości strumieni odsysanych QSC z pojedynczych cyklonów wydzielonego segmentu (kolumny) multicyklonu filtru powietrza. Badania wykonano w warunkach, gdy przez osadnik multicyklonu przepływa kolejno strumień odsysania $\mathrm{Q}_{\mathrm{SS}}$ o wartościach odpowiadających stopniu odsysania $\mathrm{m}_{0}=4,8$ i $16 \%$ i zapotrzebowaniu powietrza przez silnik $\mathrm{Q}_{\mathrm{Sil}}$ przy prędkości obrotowej mocy maksymalnej.

Do określenia wartości strumieni odsysanych $\mathrm{Q}_{\mathrm{SC}} \mathrm{z}$ pojedynczych cyklonów segmentu osadnika multicyklonu filtru powietrza wykorzystano metodę pośrednią polegającą na pomierzeniu wartości strumienia wlotowego $\mathrm{Q}_{0 \mathrm{C}}$ do cyklonu, który dla przypadku, gdy strumień wylotowy z cyklonu $\mathrm{Q}_{\mathrm{GC}}=0$ przyjmuje wartość $\mathrm{Q}_{0 \mathrm{C}}=\mathrm{Q}_{\mathrm{SC}}[6,7]$. Przypadek taki zaistnieje wtedy, kiedy otwory wylotowe z wszystkich cyklonów segmentu zostaną zasłonięte, a z osadnika pyłu segmentu odsysany jest strumień $\mathrm{Q}_{\mathrm{SS}}$ będący sumą strumieni odsysanych $\mathrm{Q}_{\mathrm{SC}} \mathrm{z}$ pojedynczych cyklonów - wzór (1), gdzie: I, II, II, ..., j, ..., J - numer kolejny cyklonu w kolumnie.

where: $\mathrm{m}_{\mathrm{s}}$ - the number of sections into which the dust collector was partitioned, $\mathrm{Q}_{\mathrm{SS}}$ - stream extracted from the dust collector of a multicyclone determined for the engine speed of the engine maximum power $\mathrm{n}_{\mathrm{N}}$ and the extraction rate $\mathrm{m}_{0}=4,8$ and $16 \%$.

The flow investigations of the dust collector section of the BWP-1 multicyclone consisting in the measurement of the values of the streams $Q_{\mathrm{SC}}$ extracted from the individual cyclones was carried out in two stages on a special test stand whose schematics has been shown in Fig. 4.

The values of the streams $Q_{\mathrm{SC}}$ extracted from the individual cyclones were determined indirectly through the measurement of the air velocity in the measurement channel in the known cross-section $A_{p}$. For this a special measurement system was used (Fig. 5) whose basic element was a fan probe of the Testo-400 device placed in a cylindrical measurement channel of diameter $\mathrm{d}_{\mathrm{c}}$.

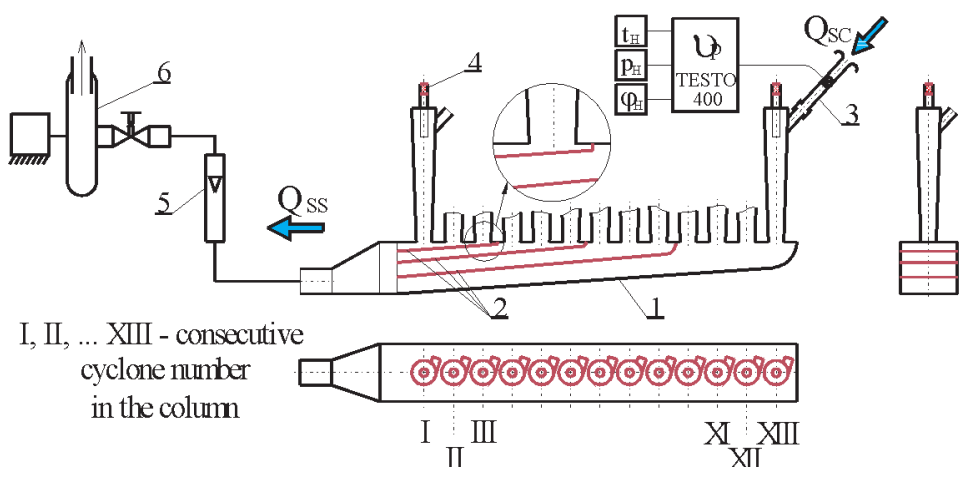

Fig. 4. Schematics of the test stand for the measurement of the streams $\mathrm{Q}_{\mathrm{SC}}$ extracted from individual cyclones of the sections of the dust collector: 1 - bottom of the dust collector section, 2 - partitions dividing the sections of the dust collector into channels, 3 - extraction stream measurement system, 4 - plug, 5 - rotameter, 6 - extraction fan

Rys. 4. Schemat stanowiska do pomiaru strumieni odsysanych $Q_{S C} z$ pojedynczych cyklonów segmentu osadnika pytu: 1 - dno segmentu osadnika pytu, 2 - przegrody dzielace komore osadnika na kanaty, 3 - układ pomiarowy strumienia odsysania, 4 - korek zamykajacy, 5-rotametr, 6-wentylator ssawny 
Due to the specific design of the cyclones in the BWP-1 multicyclone the outlet of the cylindrical measurement channel was extended with a conical connecting channel and the outlet of this channel was shaped so as to fit the elliptical cross-section $\mathrm{A}_{0}$ of the cyclone intake pipe (Fig. 5).

For the set value of the main extraction stream $Q_{\mathrm{SS}}$ the measuring system was connected to the intake pipes of the tested cyclones. For each cyclone every 10 seconds 7 values of the flowing air $v_{p j k}$ were recorded out of which an average $\bar{v}_{\mathrm{pjk}}$ was calculated. The values of the air stream flowing through the pipe was calculated fom the relation:

$$
\mathrm{Q}_{\mathrm{SCjk}}=\overline{\mathrm{v}}_{\mathrm{pjk}} \cdot \mathrm{A}_{\mathrm{p}}
$$

where: $A_{p}$ - cross-section area of the cylindrical measurement system.

The values of the streams $\mathrm{Q}_{\mathrm{SC}}$ extracted from the individual cyclones of the sections of the multicyclone dust collector were measured before and after the internal structure of the dust collector had been modified through partitioning into the extraction channels. Based on these results the authors assessed the improvement of the extraction efficiency caused by the dust collector partitioning into sections and channel partitioning into extraction channels.
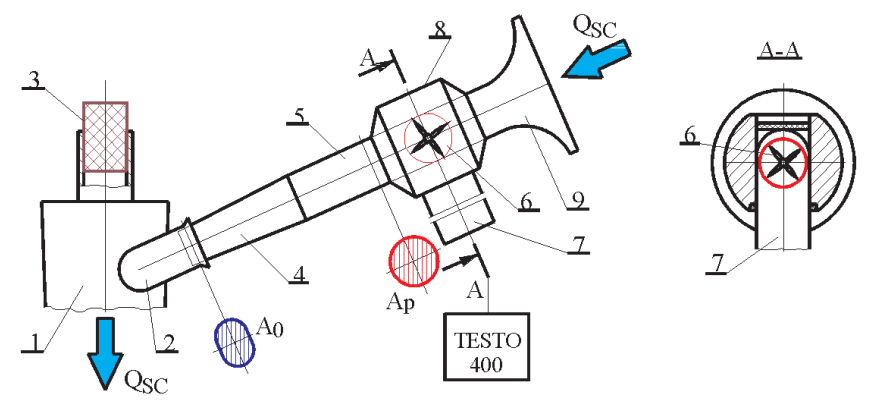

Fig. 5. Schematics of the system for the measurement of the streams $Q_{S C}$ extracted from the individual cyclones of the BWP -1 dust collector sections: 1 - cyclone block, 2 -plug, 3 - intake pipe to the cyclone, 4 - connecting channel, 5 - measurement channel, 6 - fan probe,

7 - probe jib, 8 - casing of the fan probe head, 9 - intake lemniscate

Rys. 5. Schemat uktadu do pomiaru strumieni odsysanych $Q_{S C}$ z pojedynczych cyklonów segmentu osadnika pyłu multicyklonu BWP-1: 1 - kadtub cyklonu, 2 -korek, 3 -króciec wlotowy cyklonu, 4-kanat taczacy,

5 - kanal pomiarowy, 6-wiatraczek sondy, 7-wysiegnik sondy,

8 - obudowa głowicy sondy wiatraczkowej, 9 - lemniskata wlotowa

\section{Analysis of the results}

In the first stage the values were evaluated of the streams $\mathrm{Q}_{\mathrm{SC}}$ extracted from the individual cyclones of the column in a section with the original dust collector.

In the second stage the authors measured the streams $\mathrm{Q}_{\mathrm{SC}}$ extracted from the same individual cyclones of a section where the modification of the internal structure of the dust collector had been made - the chamber was partitioned
Strumień odsysania $\mathrm{Q}_{\mathrm{SS}}$ z osadnika segmentu multicyklonu określano z zależności (2), gdzie: $\mathrm{m}_{\mathrm{S}}$ - liczba segmentów na ile został podzielony osadnik pyłu multicyklonu, $\mathrm{Q}_{\mathrm{SS}}$ strumień odsysania z osadnika multicyklonu określony dla prędkości obrotowej mocy maksymalnej $\mathrm{n}_{\mathrm{N}}$ silnika oraz stopnia odsysania $\mathrm{m}_{0}=4,8 \mathrm{i} 16 \%$.

Badania przepływowe segmentu osadnika pyłu multicyklonu BWP-1 polegające na pomiarze wartości strumieni odsysanych $\mathrm{Q}_{\mathrm{SC}} \mathrm{z}$ pojedynczych cyklonów przeprowadzono w dwóch etapach na specjalnym stanowisku, którego schemat przedstawiono na rys. 4.

Wartości strumieni odsysanych $\mathrm{Q}_{\mathrm{SC}} \mathrm{z}$ pojedynczych cyklonów określano pośrednio przez pomiar prędkości przepływu powietrza w kanale pomiarowym w przekroju o znanym polu powierzchni $A_{p}$. W tym celu zastosowano specjalny układ pomiarowy (rys. 5), w którym podstawowym elementem jest sonda wiatraczkowa przyrządu Testo400, umieszczona w cylindrycznym kanale pomiarowym o średnicy $\mathrm{d}_{\mathrm{c}}$.

Z uwagi na specyficzną konstrukcję cyklonów multicyklonu BWP-1 wylot cylindrycznego kanału pomiarowego sondy przedłużono stożkowym kanałem łączącym, a otwór wylotowy tego kanału ukształtowano tak, aby pasował do eliptycznego przekroju $A_{0}$ otworu króćca wlotowego cyklonu - rys. 5.

Dla ustalonej wartości głównego strumienia odsysania $\mathrm{Q}_{\mathrm{SS}}$ dołączano kolejno do otworów króćców wlotowych badanych cyklonów układ pomiarowy. Dla każdego cyklonu w odstępach co 10 sekund rejestrowano 7 wartości prędkości przepływającego powietrza $v_{\mathrm{pjk}}$, $\mathrm{z}$ których wyznaczano średnią $\overline{\mathrm{v}}_{\text {pjk }}$. Wartość strumienia powietrza przepływającego przez króciec określano z zależności (3), gdzie: $A_{p}$ - pole przekroju poprzecznego cylindrycznego kanału pomiarowego.

Zmierzono wartości strumieni odsysanych $\mathrm{Q}_{\mathrm{SC}} \mathrm{z}$ pojedynczych cyklonów segmentu osadnika pyłu, w którym dokonano zmiany struktury wewnętrznej osadnika poprzez podział na kanały odsysania, i przed tą zmianą. Na ich podstawie oceniono poprawę równomierności odsysania, jaką powoduje podział komory osadnika pyłu multicyklonu na segmenty i podział komory osadnika na kanały odsysania.

\section{Analiza wyników badań}

W pierwszym etapie określono wartości strumieni odsysanych $\mathrm{Q}_{\mathrm{SC}} \mathrm{z}$ pojedynczych cyklonów kolumny segmentu z osadnikiem pyłu w wersji oryginalnej.

$\mathrm{W}$ drugim etapie pomierzono wartości strumieni odsysanych $\mathrm{Q}_{\mathrm{SC}} \mathrm{z}$ tych samych pojedynczych cyklonów segmentu, w którym dokonano zmiany struktury wewnętrznej komory osadnika pyłu - podzielono komorę osadnika na kanały odsysania o wysokościach $\mathrm{h}_{1}, \mathrm{~h}_{2}, \mathrm{~h}_{3}, \mathrm{~h}_{4}$ wynikających z obliczeń numerycznych i z odpowiednim, ustalonym wcześniej, przyporządkowaniem cyklonów. W tym etapie badano kolejne zmiany konstrukcyjne segmentu osadnika pyłu multicyklonu BWP-1, oznaczając je kolejno A, B, C, aż do uzyskania zadowalającej równomierności odsysania.

Wariantem A wyjściowym segmentu był osadnik pyłu, którego komorę podzielono na cztery kanały odsysania 
into extraction channels of the heights $h_{1}, h_{2}, h_{3}, h_{4}$ resulting from the calculations with a preset cyclone assignment. At this stage further design modifications of the section of the BWP-1 multicyclone dust collector were tested and marked A, B, C until satisfactory extraction efficiency was obtained.

The output variant A of the section was a dust collector whose chamber was partitioned into four extraction channels of the heights at the outlet: $\mathrm{h}_{1}=8.5 \mathrm{~mm}, \mathrm{~h}_{2}=13 \mathrm{~mm}, \mathrm{~h}_{3}=$ $=17 \mathrm{~mm}, \mathrm{~h}_{4}=21.5 \mathrm{~mm}$ (Fig.6).

In the second stage the variants of the BWP-1 multicyclone dust collector section were tested as given in Table 1. The heights of the channels were determined through numerical calculations using the dust collector algorithm and calculation program presented earlier in the paper. o wysokościach na wylocie: $\mathrm{h}_{1}=8,5 \mathrm{~mm}, \mathrm{~h}_{2}=13 \mathrm{~mm}, \mathrm{~h}_{3}=$ $=17 \mathrm{~mm}, \mathrm{~h}_{4}=21,5 \mathrm{~mm}$ (rys. 6).

$\mathrm{W}$ drugim etapie badano warianty segmentu osadnika pyłu multicyklonu BWP-1 podane w tabeli 1. Wysokości kanałów określono numerycznie, wykorzystując prezentowany wcześniej algorytm i program obliczeniowy osadnika pyłu.

Zmiana struktury wewnętrznej komory osadnika pyłu (podział na kanały odsysania) spowodowała, że wartości strumieni odsysanych $\mathrm{Q}_{\mathrm{SC}} \mathrm{z}$ pierwszych trzech (I, II, III) cyklonów (kanał nr 1) są wyraźnie mniejsze (około 40\%) niż przed wprowadzeniem kanałów odsysania (rys. 7).

Strumienie odsysane z kolejnych trzech (IV, V, VI) cyklonów - kanał nr 2, zbliżone są najbardziej wartościami do strumieni przed podziałem na kanały. W pozostałych cy-

Table 1. Variants of the BWP-21 multicyclone dust collector section

Tabela 1. Warianty osadnika pylu segmentu multicyklonu BWP-1

\begin{tabular}{|c|c|c|c|c|c|c|c|c|}
\hline \multirow{2}{*}{$\begin{array}{l}\text { Section variant/ } \\
\text { wariant segmentu }\end{array}$} & \multicolumn{2}{|c|}{ Channel/kanat 1} & \multicolumn{2}{|c|}{ Channel/kanat 2} & \multicolumn{2}{|c|}{ Channel/kanat 3} & \multicolumn{2}{|c|}{ Channel/kanat 4} \\
\hline & $\begin{array}{l}\text { number of } \\
\text { cyclone/nu- } \\
\text { mer cyklonu }\end{array}$ & $\begin{array}{c}\text { height/ } \\
\text { wysokość } h_{I} \\
{[\mathrm{~mm}]}\end{array}$ & $\begin{array}{l}\text { number of } \\
\text { cyclone/nu- } \\
\text { mer cyklonu }\end{array}$ & $\begin{array}{c}\text { height/ } \\
\text { wysokość } h_{2} \\
{[\mathrm{~mm}]}\end{array}$ & $\begin{array}{l}\text { number of } \\
\text { cyclone/nu- } \\
\text { mer cyklonu }\end{array}$ & $\begin{array}{c}\text { height/ } \\
\text { wysokość } h_{3} \\
{[\mathrm{~mm}]}\end{array}$ & $\begin{array}{l}\text { number of } \\
\text { cyclone/nu- } \\
\text { mer cyklonu }\end{array}$ & $\begin{array}{c}\text { height/ } \\
\text { wysokość } h_{4} \\
{[\mathrm{~mm}]}\end{array}$ \\
\hline $\begin{array}{l}\text { A } \\
\text { Partitions parallel } \\
\text { to the bottom of } \\
\text { the dust collector/ } \\
\text { przegrody rów- } \\
\text { nolegte do dna } \\
\text { osadnika }\end{array}$ & I, II, III & 8.5 & IV, V, VI & 13 & VII, VIII, IX & 17 & $\begin{array}{c}\text { X, XI, XII, } \\
\text { XIII }\end{array}$ & 21.5 \\
\hline $\begin{array}{c}\text { B } \\
\text { Partitions parallel } \\
\text { to the upper } \\
\text { wall of the dust } \\
\text { collector/prze- } \\
\text { grody równolegte } \\
\text { do górnej ściany } \\
\text { osadnika }\end{array}$ & I, II, III & 8.5 & IV, V, VI & 13 & VII, VIII, IX & 17 & $\begin{array}{c}\text { X, XI, XII, } \\
\text { XIII }\end{array}$ & 21.5 \\
\hline $\begin{array}{c}\text { C } \\
\text { Partitions parallel } \\
\text { to the upper } \\
\text { wall of the dust } \\
\text { collector/prze- } \\
\text { grody równolegte } \\
\text { do górnej ściany } \\
\text { osadnika }\end{array}$ & I, II, III & 10.5 & IV, V, VI & 13 & VII, VIII, IX & 16 & $\begin{array}{c}\text { X, XI, XII, } \\
\text { XIII }\end{array}$ & 20.5 \\
\hline
\end{tabular}

The modification of the internal structure of the dust collector chamber (partitioning into extraction channels) led to a situation that the values of the streams $\mathrm{Q}_{\mathrm{SC}}$ extracted from the first three (I, II, III) cyclones (channel 1) were clearly smaller (approximately 40\%) than before the introduction of the extraction channels (Fig. 7).

The streams extracted from the following three (IV, V, VI) cyclones - channel 2 - are the closest to the values of the stream before partitioning into channels. In the outstanding cyclones (channels 3 and 4 ) a significant growth in

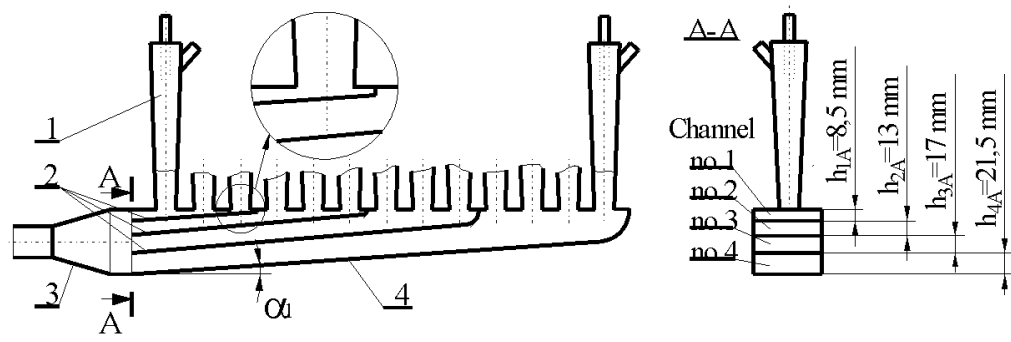

Fig. 6. Schematics of the BWP-1 multicyclone dust collector section as partitioned into extraction channels- variant A: 1 - cyclone, 2 - channel partitions, 3 - outlet manifold, 4 - bottom of the dust collector

Rys. 6. Schemat osadnika pytu segmentu multicyklonu BWP-1 z podziałem na kanaty odsysania - wariant A: 1 - cyklon, 2 - przegrody kanatów, 3-kolektor wylotowy, 4-dno osadnika 
the values of the extracted streams $Q_{S C}$ occurred as compared to the situation before the introduction of the channels. A significant variation occurred between the values of the streams extracted from the cyclones within a single extraction channel at the same value of the main extraction stream $\mathrm{Q}_{\mathrm{sS}}$. The greatest differences (more than $30 \%$ ) occurred in the cyclones within channel 1 . For the rest of the channels $(2,3,4)$ the differences were on the level of $7 \%$. The reasons for such a large difference among the streams $\mathrm{Q}_{\mathrm{SC}}$ of the first and the third cyclones are the design of channel 1 . Its height as a result of the positioning of the partition parallel to the skewed bottom of the dust collector decreases and in the final part, covering the outlet of the third cyclone, reaches a value of $1 \mathrm{~mm}$. The same may be the reason for a small value of the stream $\mathrm{Q}_{\mathrm{SC}}$ extracted from cyclone VI of channel 2. A lack of the chamber in channel 1 resulted in a very strong damping of the outflow of the streams from the final cyclones of this channel.

By positioning of the partition of channel 1 parallel lengthwise at a distance $h_{1 B}$ to the upper plate of the dust collector (variant B) a chamber of the height of $h_{1 B}=8.5$ mm was created (Fig. 8).

The outflow of the streams extracted from cyclones I, II and III is realized to a space of greater volume, which reduces the damping of the outflow of the streams from these cyclones. The partitions of the outstanding channels and the bottom of the dust collector were positioned parallel to the partition of the first channel maintaining the previous distance between them. As predicted, a decrease in the difference between the values of the streams extracted from the cyclones in channel 1 occurred. The changes in the values $\mathrm{Q}_{\mathrm{SC}}$ occurring in the outstanding channels are insignificant (Fig. 9).

At the same value of the extraction stream $Q_{\mathrm{SS}}$, there is still a great difference between the values of the streams
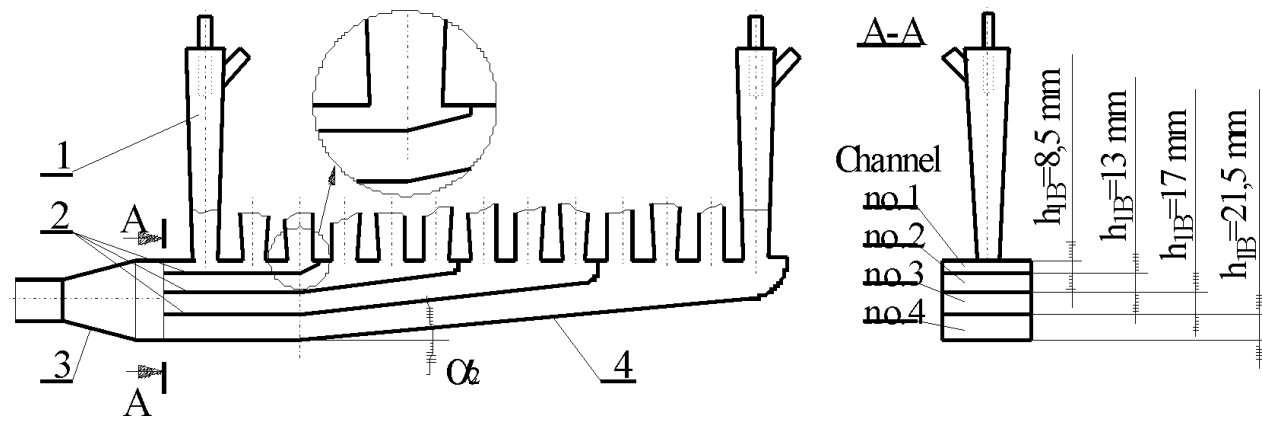

Fig. 8. Schematics of the BWP-1 multicyclone dust collector section - variant B: 1 - cyclone, 2 - channel partitions, 3 - outlet manifold, 4 - bottom of the dust collector

Rys. 8. Schemat osadnika pyłu segmentu multicyklonu BWP-1 - wariant B: 1-cyklon, 2 - przegrody kanałów, 3 - kolektor wylotowy, 4 - dno osadnika klonach (kanały nr 3 i nr 4) nastąił znaczny wzrost wartości strumieni odsysanych $\mathrm{Q}_{\mathrm{SC}}$, w porównaniu z sytuacją przed wprowadzeniem kanałów. Wystąpiło duże zróżnicowanie, przy tej samej wartości głównego strumienia odsysania $\mathrm{Q}_{\mathrm{SS}}$, pomiędzy wartościami strumieni odsysanych z cyklonów w obrębie jednego kanału odsysającego. Największe różnice (ponad 30\%) wystąpiły w cyklonach objętych kanałem $\mathrm{nr} 1$. Dla pozostałych kanałów nr 2, 3, 4 różnice te kształtowały się na poziomie 7\%. Przyczyny tak dużej różnicy między strumieniami $\mathrm{Q}_{\mathrm{SC}}$ pierwszego i trzeciego cyklonu należy szukać w konstrukcji kanału nr 1. Jego wysokość, w wyniku równoległego ustawienia przegrody do skośnego dna osadnika, zmniejsza się i w końcowym odcinku, obejmującym wylot trzeciego cyklonu, ma wartość $1 \mathrm{~mm}$. Ta sama przyczyna może być powodem małej wartości strumienia odsysania $\mathrm{Q}_{\mathrm{SC}} \mathrm{z}$ cyklonu nr VI kanału nr 2. Brak komory w kanale nr 1 spowodował bardzo silne thumienie wypływu strumieni powietrza z ostatnich cyklonów tego kanału.

Ustawiając przegrodę kanału nr 1 równolegle na całej jego długości $\mathrm{w}$ odległości $\mathrm{h}_{1 \mathrm{~B}}$ do górnej płyty osadnika pyłu (wariant $\mathrm{B}$ ), utworzono komorę o wysokości $\mathrm{h}_{1 \mathrm{~B}}=$ $=8,5 \mathrm{~mm}$ (rys. 8).

Wypływ strumieni odsysania z cyklonów nr I, II i III odbywa się do przestrzeni o większej objętości, co zmniejsza tłumienie wypływu strumieni z tych cyklonów. Przegrody pozostałych kanałów oraz dno osadnika wykonano równolegle do przegrody pierwszego kanału, zachowując poprzednie odległości między nimi. 


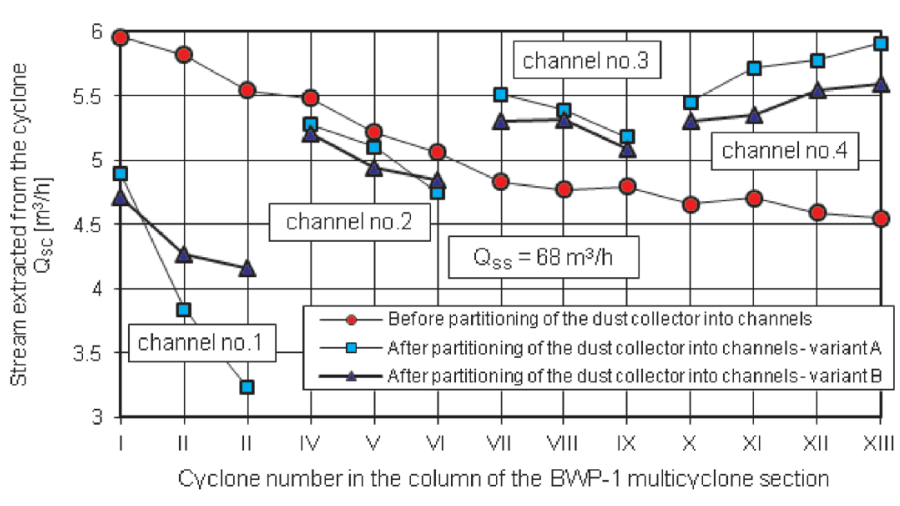

Fig. 9. The values of the streams $Q_{S C}$ extracted from the individual cyclones of the BWP-1 multicyclone section with the chamber of the dust collector partitioned into extraction channels - variant $\mathrm{C}$ and before the partitioning

Rys. 9. Wartości strumieni odsysanych $Q_{S C}$ z pojedynczych cyklonów segmentu multicyklonu BWP-1 z komora osadnika pylu podzielona na kanaty odsysaniawariant $C$ i przed podziatem

extracted from the cyclones. The greatest values of the streams $\mathrm{Q}_{\mathrm{SC}}$ occured in the cyclone of channel 4 and the smallest in channel 1, which prompted a modification in this area. The modification of the cross-section area of channels 1, 3 and 4 through changing of their heights influenced the values of the flow resistance. Hence, (variant $C$ ) the height of channel $1 \mathrm{~h}_{1 \mathrm{C}}$ was increased by $2 \mathrm{~mm}$ and heights $\mathrm{h}_{3 \mathrm{C}}$ and $\mathrm{h}_{4 \mathrm{C}}$ of channels 3 and 4 were reduced by $1 \mathrm{~mm}$. The height of channel $2 \mathrm{~h}_{2 \mathrm{C}}$ remained unchanged. The new channel heights were as follows: $\mathrm{h}_{1 \mathrm{C}}=10.5 \mathrm{~mm}, \mathrm{~h}_{2 \mathrm{C}}=13 \mathrm{~mm}, \mathrm{~h}_{3 \mathrm{C}}=$ $=16 \mathrm{~mm}, \mathrm{~h}_{4 \mathrm{C}}=20.5 \mathrm{~mm}$.

The effects of the corrections introduced in the structure of the dust collector chamber have been presented in Fig. 10. A significant evenness was obtained (reduction of differences between the greatest and the smallest values of $\mathrm{Q}_{\mathrm{SC}}$ ) of the values of the streams extracted from the cyclones within one extraction channel. The differences for channel $1 \mathrm{did}$ not exceed $5 \%$ and for the outstanding channels $-3 \%$. A significant reduction of the differences between the streams extracted from the cyclones of the adjacent channels has also been achieved. The difference between channel 1 and 4 was $4 \%$. The obtained results were deemed satisfactory and variant $\mathrm{C}$ of the dust collector-final.

The differences between the values of the streams $Q_{\mathrm{SC}}$ extracted from the cyclone within one extraction channel as well as the difference between the average values of the streams extracted from cyclones in the adjacent channels at the same value of the extraction stream $\mathrm{Q}_{\mathrm{SS}}$, did not exceed $4 \%$.

As a result of the modification of the internal structure of the dust collector (partitioning into independent sections, and the sections into the extraction channels assigned to given groups of cyclones) the authors obtained an improvement of the extraction evenness - reduction of the differences between the greatest and the smallest of the streams $\mathrm{Q}_{\mathrm{SC}}$ extracted from the individual cyclones of the multicyclone.

\section{Conclusions}

The applied methodology of the flow investigations of the separated section of the air cleaner multicyclone consisting
Nastąpiło, zgodnie z przewidywaniami, zmniejszenie różnic między wartościami strumieni odsysanych z cyklonów w kanale nr 1. Zaistniałe w pozostałych kanałach zmiany wartości strumieni $\mathrm{Q}_{\mathrm{SC}}$ są nieistotne (rys. 9).

Występuje nadal duże zróżnicowanie, przy tej samej wartości strumienia odsysania $\mathrm{Q}_{\mathrm{SS}}$, pomiędzy wartościami strumieni odsysanych z cyklonów. Największe wartości strumieni $\mathrm{Q}_{\mathrm{SC}}$ występują w cyklonach kanału $\mathrm{nr} 4$, a najmniejsze - w kanale $\mathrm{nr} 1$, co sugeruje ingerencję w tym obszarze. Zmiana pola przekroju poprzecznego kanałów nr 1, 3 i 4 przez zmianę ich wysokości wpłynie na wartości oporów przepływu. W tym celu zwiększono (wariant C) o 2 mm wysokość $\mathrm{h}_{1 \mathrm{C}}$ kanału $\mathrm{nr} 1$ oraz zmniejszono odpowiednio o 1 mm wysokości $h_{3 \mathrm{C}} \mathrm{i} \mathrm{h}_{4 \mathrm{C}}$ kanałów nr 3 i 4 . Zachowano natomiast wysokość $h_{2 C}$ kanału nr 2 . Nowe wysokości kanałów są więc następujące: $\mathrm{h}_{1 \mathrm{C}}=10,5 \mathrm{~mm}, \mathrm{~h}_{2 \mathrm{C}}=13$ $\mathrm{mm}, \mathrm{h}_{3 \mathrm{C}}=16 \mathrm{~mm}, \mathrm{~h}_{4 \mathrm{C}}=20,5 \mathrm{~mm}$.

Efekty wprowadzonych korekt w strukturze komory osadnika przedstawiono na rys. 10. Uzyskano znaczną równomierność (zmniejszenie różnic między wartością największą a najmniejszą $\mathrm{Q}_{\mathrm{SC}}$ ) wartości strumieni odsysanych z cyklonów w obrębie jednego kanału odsysania. Różnice te dla kanału nr 1 nie przekraczają 5\%, a dla pozostałych 3\%. Uzyskano także znaczne zmniejszenie różnic między średnimi wartościami strumieni odsysanych z cyklonów w sąsiednich kanałach. Różnica ta między kanałem nr 1 a nr 4 wynosi 4\%. Otrzymane wyniki uznano za zadowalające, a wykonany wariant $\mathrm{C}$ osadnika pyłu za ostateczną wersję.

Różnice między wartościami strumieni odsysanych $\mathrm{Q}_{\mathrm{SC}}$ z cyklonów w obrębie jednego kanału odsysającego, jak i pomiędzy średnimi wartościami strumieni odsysanych z cyklonów w sąsiednich kanałach, przy tej samej wartości strumienia odsysania $Q_{S S}$, nie przekraczają $4 \%$.

W wyniku przeprowadzonych zmian struktury wewnętrznej osadnika pyłu multicyklonu polegających na jego podziale na niezależne segmenty, a segmentu na kanały odsysania, którym przyporządkowano określone grupy cyklonów, uzyskano zwiększenie równomierności odsysania - zmniejszenie różnic między wartością największą a najmniejszą strumieni odsysanych $\mathrm{Q}_{\mathrm{SC}} \mathrm{z}$ pojedynczych cyklonów multicyklonu.

\section{Podsumowanie}

Zastosowana metodyka badań przepływowych wydzielonego segmentu multicyklonu filtru powietrza, polegająca na pomiarze wartości strumieni odsysania z pojedynczych cyklonów (będąca oryginalnym osiągnięciem autora) umożliwia skorygowanie wyznaczonych numerycznie wysokości $\mathrm{h}_{1}, \mathrm{~h}_{2}, \ldots, \mathrm{h}_{\mathrm{i}}$ kanałów komory osadnika pyłu w zależności od liczby przyporządkowanych im pojedynczych cyklonów dla warunków wynikających z pracy filtru w zakresie strumienia powietrza wlotowego odpowiadającego zakresowi eksploatacyjnemu prędkości obrotowej silnika i dla wartości strumieni odsysania wynikających z przyjętego stopnia odsysania.

Zmiana struktury komory osadnika pyłu multicyklonu polegająca na jego podziale na segmenty, a komory osadnika 
in the measurement of the streams extracted from the individual cyclones (author's own invention) allows a correction of the numerically determined heights $h_{1}, h_{2}, \ldots, h_{i}$ of the channels of the dust collector chamber depending on the number of assigned individual cyclones for the conditions of the operation of the air cleaner that reflect the operating engine speed range and for the value of the extracted stream resulting from the assumed extraction rate.

The modification of the structure of the chamber of the dust collector consisting in its partitioning into sections, and the chamber of the dust collector into independent, separated extraction channels resulted in a decrease of the differences (Fig. 10) between the values of the streams extracted from the individual cyclones from 3 to $5 \%$, which should render the cyclone dedusting more efficient.

In the cyclones within the extraction channels, in which, for technical reasons, a creation of a chamber is impossible and the streams extracted from the cyclones flow directly into the outlet channel of low height (channel 1) there occur significant difficulties in obtaining identical values of the extraction streams from the cyclones. Such a channel can only be assigned a single row of cyclones. For such channels the number of cyclones should not exceed two.

Paper reviewed/Artykut recenzowany

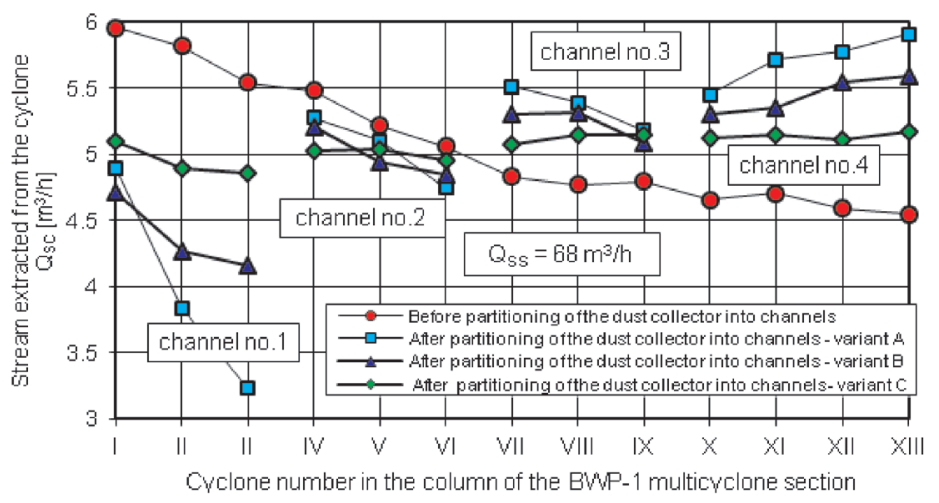

Fig. 10. The values of the streams $Q_{S C}$ extracted from the individual cyclones of the BWP-1 multicyclone section with the chamber of the dust collector partitioned into extraction channels - variant $\mathrm{C}$ and before the partitioning

Rys. 10. Wartości strumieni odsysanych $Q_{S C}$ z pojedynczych cyklonów segmentu multicyklonu BWP-1 z komora osadnika pytu podzielona na kanaty odsysaniawariant $C$ i przed podziatem

segmentu na niezależne, odizolowane od siebie kanały odsysania powoduje zmniejszenie różnic, od 3 do 5\% (rys. 10), między wartościami strumieni odsysanych z pojedynczych cyklonów, co powinno dawać większe wartości skuteczności odpylania cyklonów.

W cyklonach objętych kanałem odsysania, w których ze względów technicznych nie można wyodrębnić komory, a strumienie odsysania z cyklonów wpływają bezpośrednio do kanału wylotowego o małej wysokości (kanał pierwszy), występują duże trudności w uzyskaniu jednakowych wartości strumieni odsysania. Kanałowi temu należy przyporządkować tylko jeden rząd cyklonów. Dla pozostałych kanałów nie powinny być przypisane więcej niż dwa rzędy cyklonów.

\section{Bibliography/Literatura}

[1] Baczewski K., Hebda M.: Filtracja płynów eksploatacyjnych. MCNEMT, Radom 1991/92.

[2] Cenrtisep Air Cleaner: Materiały informacyjne firmy PALL Corporation, USA 2004.

[3] Dzierżanowski P., Miller Z.: Poszukiwania konstrukcyjnych sposobów podwyższania skuteczności bezwładnościowego odpylacza płaskiego. Biuletyn WAT, XL, 9 (469), 1991.

[4] Dzierżanowski P.: Bezwładnościowy odpylacz modułowy. Biuletyn WAT, XXXV, 2 (402), 1986.

[5] Dziubak T.: Analiza możliwości poprawy równomierności odsysania pyłu z odpylacza multicyklonowego. Silniki Spalinowe $\mathrm{nr}$ 4/2011 (147).

[6] Dziubak T.: Problemy usuwania pyłu z filtrów powietrza silników spalinowych pojazdów specjalnych. XIV Międzynarodowa Konferencja Komputerowe Systemy Wspomagania Nauki, Przemysłu i Transportu. Logistyka nr 6/2011.

[7] Dziubak T.: Analiza procesu filtracji powietrza wlotowego do silników pojazdów specjalnych. Rozprawa habilitacyjna. WAT, Warszawa 2008.

[8] Dziubak T.: Model osadnika pyłu multicyklonu filtru powietrza silnika pojazdu terenowego eksploatowanego w warunkach dużego zapylenia powietrza. Zagadnienia Eksploatacji Maszyn PAN, z. 2 (130) 2002.

[9] Dziubak T.: Problemy odsysania pyłu z multicyklonu filtru powietrza silnika pojazdu mechanicznego eksploatowanego w warunkach dużego zapylenia powietrza. Zagadnienia Eksploatacji Maszyn PAN, z. 1(125), 2001.

[10] Mann+Hummel Air Cleaners: www.mann-hummel.com.

Tadeusz Dziubak, DSc., DEng. - Professor at the Faculty of Mechanics Military University of Technology, Warsaw, Poland.

Dr hab. inż. Tadeusz Dziubak-profesor na Wydziale Mechanicznym Wojskowej Akademii Technicznej $w$ Warszawie.

e-mail:tdziubak@wat.edu.pl 